THE PLACE OF BREATH IN CINEMA 



\section{THE PLACE OF BREATH IN CINEMA}

Davina Quinlivan 
For Lambert

(C) Davina Quinlivan, 2012

Edinburgh University Press Ltd

22 George Square, Edinburgh EH8 9LF

www.euppublishing.com

Typeset in 10/12.5 pt Sabon

by Servis Filmsetting Ltd, Stockport, Cheshire, and

printed and bound in Great Britain by

CPI Group (UK) Ltd, Croydon CR0 4YY

A CIP record for this book is available from the British Library

ISBN 9780748648993 (hardback)

ISBN 9780748649006 (webready PDF)

ISBN 9780748664740 (epub)

ISBN 9780748664733 (Amazon ebook)

The right of Davina Quinlivan

to be identified as author of this work

has been asserted in accordance with

the Copyright, Designs and Patents Act 1988. 